\title{
Corrigendum: SimAlba: A Spatial Microsimulation Approach to the Analysis of Health Inequalities
}

\author{
Malcolm Campbell ${ }^{1 *}$ and Dimitris Ballas ${ }^{2}$ \\ ${ }^{1}$ GeoHealth Laboratory, Department of Geography, University of Canterbury, Christchurch, New Zealand, ${ }^{2}$ Department of \\ Economic Geography, Faculty of Spatial Sciences, University of Groningen, Groningen, Netherlands
}

\section{OPEN ACCESS}

Edited and Reviewed by: Ori Gudes, University of New South Wales, Australia

*Correspondence: Malcolm Campbell malcolm.campbel/@canterbury.ac.nz

Specialty section: This article was submitted to

Public Health Policy, a section of the journal Frontiers in Public Health

Received: 25 November 2017 Accepted: 29 November 2017 Published: 22 December 2017

Citation: Campbell M and Ballas D (2017) Corrigendum: SimAlba: A Spatial Microsimulation Approach to the Analysis of Health Inequalities. Front. Public Health 5:340. doi: 10.3389/fpubh.2017.00340
Keywords: spatial microsimulation, urban health inequalities, health policy, scotland, geographic information systems, small area microdata

\section{A corrigendum on}

SimAlba: A Spatial Microsimulation Approach to the Analysis of Health Inequalities by Campbell M, Ballas D. Front Public Health (2016) 4:230. doi: 10.3389/fpubh.2016.00230

In the original article, we neglected to include the Acknowledgments section.

\section{ACKNOWLEDGMENTS}

We acknowledge the contribution of Alison Watkins to cartographic design for Figures 1-7 in this article.

The authors apologize for this error and state that this does not change the scientific conclusions of the article in any way.

The original article has been updated.

Conflict of Interest Statement: The authors declare that the research was conducted in the absence of any commercial or financial relationships that could be construed as a potential conflict of interest.

Copyright (๑) 2017 Campbell and Ballas. This is an open-access article distributed under the terms of the Creative Commons Attribution License (CC BY). The use, distribution or reproduction in other forums is permitted, provided the original author(s) or licensor are credited and that the original publication in this journal is cited, in accordance with accepted academic practice. No use, distribution or reproduction is permitted which does not comply with these terms. 